мов у вищих навчальних закладах / Л. Смовженко // Вісник Львівського університету. Серія філологічна. - 2014. - Випуск 61. - С. 244-250.

УДК 378.013

Вікторія Устінова

\title{
МІЖДИСЦИПЛІНАРНИЙ ПІДХІ ПРИ СТРУКТУРУВАННІ ЗМІСТУ ГУМАНІТАРНИХ ДИСЦИПЛІН
}

\begin{abstract}
Устінова В. О. Міждисциплінарний підхід при структуруванні змісту гуманітарних дисциплін.

Стаття присвячена вивченню особливостей застосування міждисциплінарного підходу у процесі структурування змісту гуманітарних дисциплін. Для досягнення поставленої мети використано такі загальнонаукові методи, як аналіз і порівняння педагогічних джерел 3 проблеми дослідження; узагальнення i синтез наукового знання щодо особливостей реалізації міждисциплінарного підходу. У роботі визначено основні шляхи втілення міждисциплінарністі у фаховій підготовці студентів педагогічних ВНЗ.

Ключові слова: міждисциплінарний підхід, міждисциплінарність, міждисциплінарний зміст, гуманітарна освіта, гуманітарні дисципліни, гуманітарне навчання, структурування.
\end{abstract}

Устинова В. А. Междисциплинарный подход при структурировании содержания гуманитарных дисциплин.

Статья посвящена изучению особенностей применения междисциплинарного подхода в процессе структурирования содержания гуманитарных дисциплин. Для достижения поставленной цели использованы такие общенаучные методы, как анализ и сравнение педагогических источников по проблеме исследования; обобщение и синтез научного знания относительно особенностей реализации междисциплинарного подхода. В работе определены основные пути воплощения междисциплинарности в профессиональной подготовке студентов педагогических вузов.

Ключевые слова: междисциплинарный подход, междисциплинарность, междисциплинарное содержание, гуманитарное образование, гуманитарные дисциплины, гуманитарное обучение, структурирование.

Ustinova V. A. Interdisciplinary approach in structuring the content of the humanities.

Article is devoted to studying the particular qualities of an interdisciplinary approach in the process of structuring the content of the humanities. Scientific methods were used to achieve this goal. They are analysis and comparison of pedagogical sources for the research problem; compilation and synthesis of scientific knowledge concerning the characteristics of the implementation of an interdisciplinary approach. In this article, the main ways of interdisciplinary inplementation in the professional training of students of pedagogical universities were defined.

The urgency of the problem is caused by political and social changes that provide young people the opportunity to free self-realization in different countries, the objective necessity of formation of ideological understanding and holistic perception of the scientific and cultural development of mankind. The formation means of such a worldview is aninterdisciplinary approach in education.

The aim of the article is to reveal the role of the interdisciplinary approach in the process of humanization and humanitarization of education.

Research objectives are defined according to the purpose: to analyze the basic methodological approaches to the process of structuring the content of the humanities; to characterize interdisciplinary communication as an important pedagogical condition of formation the structuring process of the content of the humanities.

Interdisciplinary in education is one of the main directions of the organization of educational process in higher pedagogical school as it is based on the interdisciplinary nature of current 
knowledge.

Key words: Interdisciplinary approach, multidisciplinary, interdisciplinary contents, liberal education, the humanities, humane education, structuring.

Застосування міждисциплінарного підходу у процесі фахової підготовки студентів педагогічних вищих навчальних закладів розглядається як частина загальної проблеми підвищення рівня професійної, світоглядної й комунікативної компетентності випускників вищих навчальних закладів.

Актуальність проблеми зумовлена політичними та соціальним змінами, які надають молоді можливість вільної самореалізації в різних країнах світу, існуванням об'єктивної необхідності формування світоглядного розуміння й цілісного сприйняття науковокультурного розвитку людства. Засобом формування такого світосприйняття $\epsilon$ міждисциплінарний підхід в освіті.

Міждисциплінарні підходи й методи пізнання виникають на межі різних наукових дисциплін. Такі підходи притаманні сучасним науковим дослідженням. Вони відображають інтегративні тенденції в розвитку науки. Вивчення за їхньою допомогою об'єктів соціальноекономічної природи надає можливість отримати нове знання.

При структуруванні змісту гуманітарних дисциплін важливо враховувати міждисциплінарний підхід, який передбачає багаторівневу та всебічну аналітику гуманітарного феномену та його цілісне осмислення 3 позиції альтернативних інтерпретаційних стратегій, що презентують різні культурні позиції. Такий підхід повинен забезпечувати ефективність засвоєння та використання гуманітарних знань і сформувати свідомий відповідальний вибір в умовах розмаїття культурних значень, культурне самовизначення. На рівні організації освітньої практики цей аспект забезпечується варіативністю змісту гуманітарної освіти.

Необхідність міждисциплінарного синтезу соціально-гуманітарного та природничонаукового знання визнається багатьма дослідниками (А. Андреєв, О.Журавльова, В. Зінченко, Л. Мікешина, О. Міхєєва, О. Саннікова), але спосіб реалізації міждисциплінарного змісту освіти нині залишається дискусійним. Серед причин спеціалісти виокремлюють: відсутність природничо-наукових дисциплін у навчальних планах соціальногуманітарних спеціальностей; вузькотехнократична модель підготовки фахівця; відчутний розрив між викладанням гуманітарних наук у негуманітарних ВНЗ і потребами соціальної практики, на задоволення яких вивчення цих предметів повинне бути спрямовано: практика скорочення гуманітарної компоненти освіти - зменшення кількості годин на вивчення гуманітарних предметів, збіднення змісту навчального матеріалу, зниження рівня форм контролю, який використовується в навчальному процесі, щодо засвоєння гуманітарного знання (заміна екзаменів заліками) тощо. Проте, як показують проведені науковцями спостереження [1, с. 100], вузькопрофесійний підхід до освіти, спрямований на засвоєння тільки тих знань, умінь і навичок, які явно необхідні для розв'язання чисто професійних і ділових задач, серед молоді не дуже популярний. Більшість уважає, що гуманітарна підготовка є невід'ємною ознакою освіченості й одночасно ключем до вироблення більш адаптивних стратегій особистісної самореалізації- від чисто прагматичного планування кар'єри до задоволення духовних потреб. Усе вищезазначене сприяє формуванню в студентському середовищі широких інтересів гуманітарного плану: міжнародні відносини, психологія, зв'язки з громадськістю (PR), всесвітня історія, основи дизайну тощо, що пояснюється тим фактом, що гуманітарне знання охоплює науки про людину, науки про суспільство, науки про взаємодію людини та суспільства, прогностику суспільних процесів і розвитку людської природи.

Метою статті є розкриття ролі міждисциплінарного підходу у процесі гуманізації та гуманітаризації освіти.

Відповідно до мети визначено завдання дослідження: проаналізувати основні методологічні підходи щодо процесу структурування змісту гуманітарних дисциплін; 
схарактеризувати міжпредметні зв'язки як важливу педагогічну умову формування процесу структурування змісту гуманітарних дисциплін.

Отже, одним із головних напрямків організації навчального процесу у вищій педагогічній школі повинна стати міждисциплінарність у навчанні, підгрунтя якої становить міждисциплінарна природа сучасного знання. В умовах сьогодення, як показує практика, міждисциплінарність утілюється двома шляхами: 1) інтенсивне введення в технічних ВН3 дисциплін гуманітарного циклу: 2) збагачення гуманітарних спеціальностей і дисциплін основами технічного та природничо-наукового знання й навпаки. На нашу думку, утілення ідеї міждисциплінарності при структуруванні гуманітарних дисциплін сприяє формуванню у студентів нестандартного мислення, розуміння глобалізаційних процесів у суспільстві й науці, здатності до розв'язання комплексних проблем, які виникають на стику різних галузей, бачити взаємозв'язок фундаментальних досліджень, технологій і потреб виробництва й суспільства, уміти оцінювати ефективність певної інновації, організовувати її практичне втілення тощо.

Гуманітарна освіта інтегрується 3 природничо-науковою освітою, яка забезпечує об'єктивність, точність і послідовність методичних і технічних аспектів гуманітарної освіти. Зазначена інтеграція відбувається на основі синтезу теоретичної та практичної діяльності, унаслідок чого гуманітарна освіта набуває прагматичності. Так, метод проектів дозволяє розкрити iі практико-орієнтований характер i запропонувати прагматичний критерій гуманітарного навчання. За його допомогою до процесу навчання можна залучити соціальне середовище, що є необхідною умовою формування соціальної та регіональної компетенцій, здатності до ефективних соціальних дій [5, с. 233].

3 урахуванням специфіки професійної спрямованості студентів - майбутніх учителів міждисциплінарний зміст гуманітарних дисциплін необхідно розглядати в динаміці суб'єктно-орієнтованого співвідношення між природничо-науковою та гуманітарною особливостями наукового пізнання в межах освітньої ситуації [2, с. 101]. Міждисциплінарний характер гуманітарних дисциплін визначається його спрямованістю на розкриття особливостей природничо-наукового мислення через розкриття специфіки гуманітарної культури, гуманітарного мислення, на визначення межі між ними, можливостей змінити цю межу, перенести інструментарій на природничо-наукову або гуманітарну предметність.

3 огляду на сказане, міждисциплінарний зміст повинен мати всі функціональні характеристики гуманітарного знання: ціннісну, смислову, комунікативну [3, с. 98]. Так, освоєння ціннісної характеристики пов'язується зі здатністю студента визначати та розуміти значущість природничо-наукового знання в культурі, його важливість для самовизначення індивіда у світі, для професійного самовизначення. Освоєння комунікативної характеристики залежить від здатності студента встановлювати сфери перехрещення смислів природничо-наукових понять із проблематикою гуманітарного пізнання, визначати взаємозв'язок мов опису природної та соціогуманітарної реальностей.

Отже, урахування міждисциплінарного характеру гуманітарних дисциплін дозволяє виконати освітне завдання: показати, що для гуманітарного та природничо-наукового знання стандарти формалізації й об’єктивовані нормативи мають двоєдину - логічну та комунікативну - природу, зумовлену ціннісним змістом соціокультурного контексту епохи.

На сучасному етапі розвитку освіти в різних педагогічних ВНЗ упроваджуються дисципліни міждисциплінарного характеру, 3-поміж них: «Концепція сучасного природознавства», «Економічна теорія», «Педагогічна взаємодія», «Сучасні педагогічні технології», «Культурологія», «Міжкультурна комунікація» тощо.

Дослідники підкреслюють, що розвиток гуманітарної освіти, 3 урахуванням виконання поставлених завдань і визначених тенденцій розвитку освіти та гуманітарних знань, передбачає реалізацію принципу відкритості гуманітарної освіти соціальним практикам і принципу іiї доступності без обмежень віку та географічного положення, а також формування інтенції до безперервної освіти та здатності до самоосвіти за допомогою 
створення структур, форм і технологій, що їх забезпечують. В інформаційному суспільстві особлива роль у розв'язанні цього завдання належить дистанційній освіті.

Слід зауважити, що становлення інформаційного суспільства змінює парадигму мислення: теоретичне фундаментальне мислення, яке грунтується на зразках науки, перебуває у кризі, тому що втрачається єдиний культурний вектор, при цьому соціальні практики стають інтелектуально насиченими, підвищуються вимоги до свідомої цілеспрямованої діяльності. Отже, сучасна гуманітарна освіта стає фундаментальною підготовкою, яка визначається не трансляцією фундаментальних знань (універсальний та єдиний контекст дослідження втратив силу), а зорієнтованого на формування творчої здатності як фундаментальної структури людського буття, на концептуалізацію діяльності, що має продуктивні теоретичні потенції.

Міждисциплінарний підхід сприяє реалізації всіх дидактичних принципів навчання. Перспективами подальших досліджень $є$ опис практичної реалізації міждисциплінарного підходу на заняттях іноземної мови.

\title{
Література
}

1. Андреев А.Л. Гуманитарное образование : очередной кризис? / А. Л. Андреев // Высшее образование в России. - 2004. - № 7. - С. 95-103. 2. Завьялова М. П. Изменения установок гуманитарного образования в условиях становления информационного общества [Электронный ресурс] / М. П. Завьялова, Д. В. Сухушин // Открытый междисциплинарный электронный журнал «Гуманитарная информатика». - Вып. 1. - Томск : Томский гос. ун-т. Режим доступа: http://huminf.tsu.ru/e-jurnal/magazine/1/zavalov.htm 3. Санникова О. В. Междисциплинарность содержания социально-гуманитарного образования : социокультурные основания / О. В. Санникова // Высшее образование в России. - 2009.№ 4. - С. 98-103. 4. Микешина Л. Л. Трансцендентальное измерение гуманитарного знания / Л. Л. Микешина // Вопросы философии. $-\quad 2006 .-\quad № 1 .-\quad$ С. 46-67. 5. Хуторской А. В. Дидактическая эвристика. Теория и технология креативного обучения : [монография ] / Андрей Викторович Хуторской. - Москва : Изд-во МГУ, 2003. - 416 с.

$$
\begin{gathered}
\text { УДК (37.026:159.922.72)-043. } 86:([005.336 .2: 17.023 .36-\quad \text { Дар’я Фурт } \\
022.218]: 373.5 .046-021.66
\end{gathered}
$$

\section{ДИДАКТИЧНІ УМОВИ РОЗВИТКУ ПОЛІКУЛЬТУРНОЇ КОМПЕТЕНТНОСТІ СТАРШОКЛАСНИКІВ}

\author{
Фурт Д. В. Дидактичні умови розвитку полікультурної компетентності \\ старшокласників. \\ У статті проаналізовано погляди науковців на досліджувану проблему, визначено
} основні дидактичні умови розвитку полікультурної компетентності старшокласників на уроках англійської мови. 3'ясовано поняття «дидактичні умови»; розглянуто основні форми роботи зі старшокласниками та визначено необхідні чинники для ефективного розвитку полікультурної компетентності. У роботі наголошено, що за умов методично грамотно організованої роботи 3 розвитку полікультурної компетентності, учні опановують загальноприйняті норми мовного спілкування і мовної поведінки в культурному середовищі, мова якого вивчається, та у своєму рідному.

Ключові слова: умови, дидактичні умови, полікультурна компетентність, розвиток полікультурної компетентності, старшокласники, форма роботи, мовне середовище.

Фурт Д. В. Дидактические условия развития поликультурная компетентность старшеклассников.

В статье проанализированы взгляды ученых на исследуемую проблему, определены основные дидактические условия развития поликультурной компетентности старшеклассников на уроках английского языка. Выяснено понятие «дидактические 